\title{
Respon Global Terhadap Dominasi Ekonomi China
}

\author{
Melaty Anggraini \\ email: melaty.anggraini@upnyk.ac.id \\ Jurusan Hubungan Internasional Fakultas Ilmu Sosial dan Ilmu Politik Universitas \\ Pembangunan Nasional "Veteran" Yogyakarta
}

\begin{abstract}
The Resurgence of Economic China started from strategic Deng xiao ping Era, which is open reformation era and, the open policy becomes foster of the growth of economic China. Even though it needed a difficult long process for the growth of the economic system, china can prove and become a developing country which had label "Newly Industrialized Countries." A Resurgence of Economic China caused the domination effect for countries surrounded, and suspicious for them so caused response from another country. Response who is got China more to anticipated way cause many countries think China will make expansion economic. For response that needs disruption mindset so every country didn't scrape with issues economic and international trade how can more weaken position country which had a cooperation with China in the global economic politic system. For that, the author invited readers for an understanding of the way to responses resurgence of economic China to handle and can get benefit from the economic growth of China.
\end{abstract}

Keywords: Global Response, Economic China, Disruptive Mindset.

\section{A. Pendahuluan}

Pertumbuhan ekonomi semakin meningkat, dan diperkirakan ekonomi China akan menandingi Amerika Serikat. Dapat dilihat selama empat dekade terakhir pertumbuhan ekonomi China semakin berkembang, China menjalin kemitraan dengan lebih dari 100 negara dibandingkan dengan Amerika Serikat yang tercatat hanya bermitra setengah dari Negara mitra China. Meskipun sekarang pertumbuhan ekonomi China sedikit melambat tetapi dalam waktu pertahun selalu meningkat $6 \%$ diatas pertumbuhan nilai ekonomi Amerika Serikat. Selain mendominasi di bidang Ekonomi, China juga sudah menerapkan strategi ekspansi ke bidang militer dan energy dengan membangun aliansi militer ke berbagai Negara seperti Rusia, menerapkan grand strategy energy ke wilayah Asia Tenggara dan Afrika serta berencana menandingi 
Amerika dalam menerapkan Space Minning ke luar angkasa dengan rencana membuat pemukiman cadangan di Mars untuk mendapat energy terbarukan.

Melalui inisiatif One Belt One Road, semakin membantu China dalam membangun kemitraan ekonomi ke Negara di wilayah Eropa, Afrika dan Asia Tenggara dan meningkatkan kepercayaan seluruh Negara terhadap China. Kinerja perkembangan ekonomi China dalam jangka waktu 4 dekade semakin mengesankan, dan banyak pakar ekonomi yang meramalkan bahwa China akan menggantikan posisi Amerika Serikat dalam era selanjutnya sebagai negara super power. Menurut bank dunia Keberhasilan pembangunan ekonomi China yang lebih cepat dari negara maju lainnya, seperti Inggris yang memerlukan waktu 58 tahun dan Amerika Serikat 47 tahun, Jepang berkisar 38 tahun untuk menaikkan tingkat PDB nya namun China hanya memerlukan yaitu sekitar 8,6 tahun untuk menggandakan pendapatan perkapitanya dan bangkit dari keterpurukkan sehingga dapat menguasai ekonomi global (Yulu, 2019). Hal ini menimbulkan berbagai respon dunia. Termasuk bagi Amerika Serikat yang sampai saat ini masih memegang kekuasaan terhadap struktur ekonomi dunia.

Respon tersebut tidak hanya muncul di negara-negara maju, bahkan negaranegara kecil yang telah menjadi mitra strategis China juga ikut merespon terhadap pertumbuhan ekonomi China, kemurahan hati China dalam berbisnis dan menjalankan inisatif perdagangan One Belt One Road perlu dicermati dengan baik. Setiap negara perlu mewaspadai dengan meluasnya ekspansi China melalui ambisi teknologi yang dijalankan untuk memacu pertumbuhan ekonominya serta bantuan luar negeri China terhadap negara mitranya agar tidak terjadi penetrasi ekonomi dengan tekanan-tekanan politik yang merugikan. Seperti yang telah diramalkan oleh para pakar ekonomi sebelumnya, bukan tidak mungkin ambisi ekonomi China dapat menjadi sebuah polemik yang akan mendompleng hegemoni barat dan menggantikan posisi Amerika Serikat sebagai negara imperialis baru.

Dalam penelitian ini akan lebih menganalisa, awal proses kebangkitan China sampai menjadi negara besar seperti sekarang, dan tingkat respon yang ditimbulkan beberapa negara akibat ekspansi ekonomi China serta bagaimana metode yang dapat 
diambil dan diperlukan untuk merespon rasa kekahwatiran terhadap ambisi politik ekonomi global China.

\section{B. Rumusan Masalah}

Kemurahan hati China dalam berbisnis, dan semakin luasnya ekspansi ekonomi China di tingkat global menimbulkan kekhawatiran dunia terhadap pertumbuhan ekonominya. Untuk itu perlu dianalisa berbagai respon yang ditinggalkan seluruh dunia dalam menanggapi kebangkitan ekonomi China, dan mencari respon yang paling sesuai untuk kecurigaan tersebut agar tidak merugikan berbagai negara yang terlibat dalam sistem perekonomian global.

\section{Kerangka Analisis}

\section{a. Disruptive Mindset}

Setiap orang pasti pernah merasa gagal dan kegagalan tersebut terkadang menjadi batu analisis untuk memperbaiki kesalahan, sehingga kita bisa bangkit dari kesalahan. Tetapi Disruptive mind adalah cara berpikir berbeda bukan belajar dari proses kegagalan untuk mencapai keberhasilan melainkan bagaimana menciptakan suatu perubahan sebelum mengalami suatu kegagalan. Jadi strategi yang diciptakan di awal sebelum mengalami kegagalan, atau lebih kepada kekhawatiran adanya kegagalan setelah rencana dijalankan. Bagaimana caranya, yaitu dengan mudah bisa membaca situasi dan menangkap sinyal-sinyal yang jelas dan nyata akan adanya perkembangan baru yang dapat secara mendadak bangkit dan menggerus rencana yang akan dijalankan. Sehingga dapat dengan mudah beradaptasi dengan kondisi yang baru atau perubahan yang terjadi. Selain itu memiliki mental pejuang yang berpikiran terbuka dan ini dinyatakan dengan mempelajari umpan balik. Mental disruptive ini tidak terikat oleh pengalaman atau hanya belajar dari masa lalu sehingga terkekang dengan aturan yang baku tetapi memerlukan sikap yang terbuka yang lebih berorientasi dengan keadaan masa depan. Untuk menghasilkan perubahan, hal yang pertama harus dilakukan adalah dengan melihat "Seeing is Believing", artinya kita telah melakukan analisa dan pengamatan yang mendalam terlebih dahulu sehingga bisa mengambil langkah yang 
adaptive terhadap situasi terkini. Melihat perubahan dan berada di dalam gelombang disruption tentu saja sedikit berbeda dengan melihat sesuatu yang dengan mudah terlihat. Perubahan adalah sesuatu yang sulit terlihat, meskipun perubahan sejalan dengan berjalannya waktu namun kurang diperhitungkan, seperti perubahan komponenkomponen kecil sistem pemerintahan yang secara perlahan akan mengganti sistem pola pikir masyarakat dalam bertindak. Tetapi masih banyak orang yang belum menyadari bahkan menyangkal perubahan tersebut. Setelah kita menyadari perubahan kompleks yang terjadi dalam kehidupan, tidak seharusnya hanya berdiam diri dan menikmati perubahan tersebut. Tetapi kita juga perlu turut andil dan bergerak secara langsung untuk memanfaatkan roda perubahan tersebut. Tidak hanya bergerak, tetapi harus menjalankan sampai tuntas sampai dirasa perubahan tersebut memiliki manfaat yang cukup besar bagi keberlangsungan hidup umat manusia. Begitupula perubahan yang diwujudkan oleh pertumbuhan ekonomi China, kita harus menanamkan disruptive mindset untuk merespon setiap langkah perubahan yang diciptakannya dan mengejar ketertinggalan langkah dan menciptakan peluang agar dapat bangkit seperti China.

\section{b. Complementary Interest}

Cara yang paling mudah untuk memahami perkembangan era globalisasi adalah dengan cara ikut serta dalam arena internasional, dari situ kita akan memahami wujud perkembangan yang terjadi akibat evolusi perubahan. Untuk masuk ke arena internasional maka kita perlu melakukan pola kerjasama internasional, dan hal tersebut tidak akan terbentuk apabila tidak memenuhi kepentingan yang saling melengkapi atau Complementary Interest. Cara yang paling mudah dalam memahaminya adalah dengan saling membuat kompensasi yang saling menguntungkan bagi kedua pihak yang melakukan kerjasama. Dalam kerjasama politik internasional complementary interest diwujudkan dalam wacana barter issu atau issue linkage. Disini ada pihak yang berperan sebagai actor yang memberikan tawaran isu yang akan mewujudkan kepentingannya atau biasa disebut Linker. Dan ada pihak yang bertindak sebagai Linkee, pihak yang ditawari bentuk kompensasi yang nantinya kepentingan linkee akan tereduksi dengan bentuk kerjasama dan kompensasi tersebut. Namun bentuk kerjasama ini perlu memetakan terlebih dahulu tingkat kepentingan satu sama lain, sehingga akan 
mudah menganalisa bayangan keuntungan di masa depan. Meskipun nantinya tidak semua pihak akan terpenuhi wujud kepentingannya, karena bentuk kerjasama ini memerlukan sikap yang saling konsisten sehingga tidak merugikan satu sama lain. Sehingga nantinya bentuk kerjasama ini akan mengarah ke bentuk keuntungan absolute gain dan relative gain yang berarti bila mengarah ke bentuk pertama, kedua belah pihak dalam negosiasi diraih tanpa mengalami loss atau kerugian yang cukup banyak. Dan bila mengarah ke bentuk keuntungan kedua, capaian suatu pihak diraih secara minimal setelah mengalami loss. Dalam arti lain kedua belah pihak berpikir secara rasional, bahwa kerjasama yang dilakukan meskipun mengalami kegagalan setidaknya sudah pernah dicoba dan sedikit meraih keuntungan dibandingkan tidak melakukan kerjasama sama sekali.

\section{c. Strategi Constructive Engagement dan Hedging}

Konsep terakhir yang dipakai adalah Model Constructive Engagement dan Hedging, konsep ini merupakan sebuah pendekatan terhadap isu keamanan dan strategi. Pertama kali muncul sebagai bentuk respon AS terhadap hubungannya dengan Afrika Selatan di tahun 1970-1985(Coker, 1986). Konsep yang dipakai ini lebih mengarah kepada penerapan sanksi dan isolasi yang menimbulkan konfrontasi antara kedua belah pihak yang bertikai dan wujud dari kebijakan luar negeri suatu negara, dalam hal ini AS. Constructive Engagement didasarkan pada sebuah premis bahwa dimungkinkan menerapkan tekanan terhadap pihak lain untuk menghasilkan perubahan yang bersifat konstruktif tanpa menggunakan metode paksaan terhadap suatu pihak (Crocker, 1986). Penolakan penggunaan sanksi dan strategi isolasi oleh model Constructive Engangement berakar asumsi mengenai tingkat keefektifitasannya. Sebab menurut model ini terdapat hubungan yang kuat antara aspek politik dan ekonomi yang tidak dapat dipisahkan. dalam hal ini aspek ekonomi sendiri meliputi kerjasama dalam bidang ekonomi, melalui berbagai bentuk kerjasama dalam bidang ekonomi ini maka diyakini dapat mendorong perubahan politik di dalam suatu negara (Ivanica, 1998). Oleh sebab itu jika ingin mendorong transisi sistem politik dalam negeri suatu negara maka hal lain yang harus diperhatikan ialah pentingnya untuk membentuk kerjasama dalam bidang ekonomi yang bertujuan untuk mendorong pertumbuhan ekonomi dan pembangunan 
nasional yang pada gilirannya akan mendukung keberlangsungan demokratisasi suatu negara. Model Constructive Engagement meyakini bahwa perubahan dalam sistem politik dapat dicapai apabila didukung oleh kondisi ekonomi dan sosial yang baik untuk menopang proses demokrasi yang terjadi dalam negeri. Sedangkan konsep Hedging merupakan strategi alternative dari balancing, bandwagoning, dan buck-passing dari kerangka teori balance of Threat. Hedging dilaksanakan ketika negara tersebut tidak terlalu yakin dengan sumber ancaman yang, strategi ini lebih mengarah kepada jalinan hubungan dengan mitra yang perilakunya tidak bisa ditebak di masa mendatang, yang mengandalkan seperangkat kebijakan yang membantu mempererat hubungan bilateral kedua belah pihak juga nantinya akan membantu negara tersebut membangun insurance policy terhadap ancaman potensial yang ditimbulkan oleh mitranya.

\section{Pembahasan}

\section{a. Model Ekonomi Pembangunan China}

Banyak orang belum mengenal negara seperti apakah China, sehingga ketika pertumbuhan perekonomiannya semakin maju membuat berbagai negara takjub dan menjadi pembicaraan yang sangat kontroversial. Pertumbuhan ekonomi china berkembang luar biasa, negara ini menyumbang 7,9\% dari output ekonomi seluruh dunia, dan volume perdagangan luar negeri sebesar $8 \%$ dari total volume dunia pada tahun 2009. Cadangan devisa menyumbang sebanyak 28\% dari cadangan devisa global, dan jumlah investasi asing negara ini selalu berada di peringkat tiga besar selama decade terakhir. Percepatan modernisasi dari semenjak pemerintahan Deng Xiaoping membuka reformasi dan keterbukaan negara telah menjadi sebuah mesin pendorong yang penting dalam stabilitas dan pemulihan ekonomi global. Untuk itu kita perlu memahami negara seperti apa China dan bagaimana bisa meraih kesuksesan tersebut.

China memiliki karakteristik unik tersendiri, negara yang dikenal sebagai negara komunis sosialis ini bertransformasi ke sosialis pasar dan membentuk negara yang penuh antusiasme terhadap pembangunan masa depan. Dari menganut sistem perekonomian terencana menjadi lebih ke sistem ekonomi terbuka atau pasar sosialis. Namun terbuka disini masih memainkan karakteristik China tersendiri yaitu 
pembangunan di masa depan harus dilakukan sesuai dengan kondisi nasional. Negara ini tidak ingin meniru model pembangunan manapun, sebaliknya akan mengadopsi model pembangunan berkelanjutan dengan karakteristik negaranya sendiri. Maksudnya disini, China akan melihat kondisi masyarakatnya terlebih dahulu untuk menyesuaikan model pembangunannya, apa yang sebenarnya menjadi kelemahan masyarakat China yang perlu dilakukan perubahan dan apakah perubahan tersebut siap dengan kondisi budaya masyarakat China. Setelah analisa tersebut pola pembangunan akan lebih mengacu pada pola berpikir yang didasarkan kepentingan dan pengembangan bersama dan mendorong komunikasi lintas budaya. Karena pemikiran inovatif biasanya terjadi dengan dengan interaksi budaya yang berbeda serta mendorong pembentukan sistem manajemen global berdasarkan saling percaya. Sebagai contoh, china memiliki ukuran wilayah yang tidak terlalu besar namun populasi nya cukup besar, pemerintah China akan melihat bahwa nantinya akan ada keterbatasan sumber daya alam dan energi untuk memenuhi kebutuhan populasi yang berlebih tersebut, untuk itu pembangunan ekonomi China akan lebih berorientasi dengan mengedepankan pola urbanisasi agar terjadi pemerataan penduduk dan mencari sumber energi alternative bagi masyarakat China. Selanjutnya, China memiliki impian yang sangat sederhana namun menjadi prinsip pengembangan ekonomi China. Impiannya adalah menghilangkan polarisasi dan mencapai kemakmuran bersama. Polarisasi dapat memecah rakyat China dan akhirnya menimbulkan konflik domestik, sedangkan syarat pertumbuhan ekonomi yang baik adalah keseimbangan antara kekuatan domestik dan kemampuan finansial. Proses pembangunan tidak akan terfokus apabila terlalu banyak masalah internal sehingga sulit untuk mengejar ketertinggalan dari negara maju. Realisasi impian tersebut memerlukan pembangunan ekonomi yang konstan dan kemajuan di semua aspek masyarakat. Faktor kuncinya terletak pada sumber daya dan lingkungan serta penurunan kesenjangan antara si kaya dan si miskin. Kendala sumber daya dan lingkungan dapat diatasi oleh China dengan penanaman modal skill dengan memajukan teknologi, menyesuaikan struktur perkotaan, pedesaaan, industri, mengubah gaya konsumsi, dan membangun sistem pasar dan sistem tata kelola pemerintahan berorientasi ke kemajuan sumber daya manusia sehingga dapat bergerak menuju pembangunan yang berkelanjutan. 
Terakhir, China memiliki model pembangunan tersendiri tanpa dipengaruhi model pembangunan ala barat atau ala eropa, yang lebih dikenal dengan ekonomi pasar sosialis. Atau sosialisme dengan karakter China. Model ini lebih menekankan pada peng-kombinasian kebijakan top-down dan bottom up, maksudnya pemerintah dan negara tetap kuat mengendalikan sistem politik dan kebijakan ekonomi, tetapi dalam waktu yang sama pemerintah mendorong desentralisasi sehingga rakyat memiliki peluang partisipasi dalam menentukan arah pembangunan dan akan memacu kompetisi. Model ini terbukti meningkatkan kekuatan ekonomi negara China, dengan pertumbuhan tanpa krisis selama 30 tahun. Model ini didapat dari menganalisa kondisi masyarakat China sendiri dan melakukan transformasi ekonomi secara perlahan, model ini dirangkum dalam konsesus Beijing. Konsesus Beijing menekankan pada pola pengembangan pembangunan berbasis inovasi dan kerja keras berdasarkan tingkat kebutuhan, yang berarti ilmu pengetahuan dan teknologi akan menjadi fondasi untuk pembangunan ekonomi dan masyarakat di masa depan. Membangun negara yang berorientasi inovasi membutuhkan peningkatan kontribusi dari sains dan teknologi. Seperti giat meningkatkan pengetahuan dan mendorong pemikiran inovatif, mentransformasi pengetahuan menjadi paten untuk menghubungkan dengan produksi, dan mencapai konsesus tentang pertumbuhan ekonomi dan mentransformasikan kemajuan dan hak paten teknologi menjadi pertumbuhan ekonomi.

\section{b. Kemunculan China sebagai negara imperialis baru}

Dengan mengadopsi model pembangunan sendiri, pertumbuhan ekonomi China melesat cepat. Pertumbuhan China menjadi sorotan dunia ketika China berhasil mempertahankan negaranya dari terkena dampak krisis, pertumbuhan yang tinggi selama era reformasi dan keterbukaan tanpa krisis selama 30 tahun menjadi sejarah keberhasilan China dalam sistem perekonomian global. Dalam beberapa tahun terakhir pertumbuhan ekonomi China yang berkecepatan tinggi selalu bisa mempertahankan kestabilan ekonomi meskipun terjadi berbagai krisis ekonomi dunia, sampai ke krisis finansial global yang terakhir China tetap bisa mempertahankan kestabilan ekonominya. Hal ini yang menarik perhatian dunia, dan para pakar ekonomi mulai banyak memprediksikan bahwa China bisa muncul menjadi negara superpower yang baru yang 
dapat menjadi tandingan Amerika Serikat sebagai negara pemegang benevolent hegemony dunia.

Sejak dimulainya era reformasi dan keterbukaan negara ini sudah menarik perhatian dunia dengan pertumbuhan PDB selama 30 tahun terakhir telah mencapai 10\%. Berdasarkan data historis, negara China mengalami tingkat pertumbuhan ekonomi tertinggi selama periode ini, menikmati pertumbuhan dalam kurun waktu paling panjang dan menguntungkan paling banyak orang dalam sejarah dunia. Tingkat pertumbuhan negara China lebih dari 5 kali tingkat pertumbuhan PDB dunia perkapita adalah 1,5\% pada periode yang sama. Pada tahun 2009, nilai ekonomi China telah mencapai USD 4, 19 Trilliun, hanya berada di bawah AS dan Jepang. Nilai nominal PDB China menyumbang 8\% dari agregat ekonomi global (Yulu, 2019). Data ini membuktikan bahwa China hanya memerlukan satu generasi untuk mencapai apa yang dilakukan negara lain selama berabad-abad, untuk kemampuan sebuah negara dengan populasi besar setara Afrika dan Amerika Latin. Tak diragukan lagi china dapat diramalkan sebagai negara “Emerging Superpower” sekelas Amerika Serikat.

Meskipun ada sejumlah pencapaian, 30 tahun pertama pendirian republic China tidak mengalami pertumbuhan ekonomi yang signifikan, namun Partai Komunis China berhasil merubah perjuangan partai dari revolusioner menjadi partai untuk konstruksi ekonomi. Secara keseluruhan, sejak era reformasi dan keterbukaan, ada kira-kira tiga tahap dalam pembangunan ekonomi China:

$\infty$ Tahap pertama adalah dari tahun 1978 sampai 1999, ditandai dengan perubahan politik yang luar biasa. Perkembangan ekonomi selama periode ini relative siklis, sesuai dengan peristiwa politik, seperti pemerintahan baru dan konvensi partai politik.

$\infty$ Tahap kedua, dari tahun 1992 - 1999, sebuah periode dengan ekspansi cepat. Pada tahun 1992, komite partai pusat menargetkan ekonomi pasar sosialis sebagai tujuan untuk restrukturisasi ekonomi China. Dengan perkembangan sektor-sektor milik negara, arus investasi asing yang masuk secara konstan, dan peningkatan ekspor yang terus menerus meningkat. Negara China memasuki periode pertumbuhan 
ekonomi dengan percepatan tinggi, rata-rata tingkat pertumbuhan ekonomi pada periode ini $10,9 \%$.

$\infty$ Tahap ketiga dimulai dari tahun 2000 hingga sekarang. Ini adalah periode pertumbuhan yang stabil dengan kecepatan tinggi. Setelah tahun 2000 pada dasarnya ekonomi pasar sosialis terbentuk dan pola pertumbuhan ekonomi serta struktur industri berubah menjadi lebih optimal dengan proposal strategi nasional yang inovatif, negara China memasuki perkembangan ekonomi baru yang ditandai dengan karbon rendah, skala ekonomi, stabilitas, dan inovasi.

Dengan percepatan globalisasi ekonomi dan keuangan, negara China sebagai ekonomi terbuka memegang peran yang semakin penting dalam arena politik dan ekonomi internasional. Ketika krisis global menimbulkan malapetaka pada kekuatan ekonomi besar, ekonomi China memiliki kinerja yang cukup baik. Pada tahun 2009 tingkat pertumbuhan PDB nya mencapai 9,1\% dan kontribusinya terhadap pemulihan ekonomi global lebih dari 50\%. China tanpa disadari menjadi mesin pertumbuhan ekonomi global, tanda "Made in China" di seluruh dunia adalah sinyal penting yang menyatakan negara China telah menjadi bagian Integral dari ekonomi global (Yulu, 2019).

\section{c. Kelebihan China dari negara lainnya}

Sebelumnya telah dijelaskan bahwa China dapat menghindari semua bentuk krisis finansial global, dan menjadi pusat perhatian dunia. China menjadi semakin diperhatikan bukan hanya karena pertumbuhan ekonomi atau karena luas wilayahnya tetapi juga karena pengaruh yang signifikan terhadap kekayaan perusahaan-perusahaan global. Pertumbuhan, stabilitas, dan potensi negara China menarik sejumlah besar perusahaan asing. Dengan pertumbuhan ekonomi berkecepatan tinggi dan integrasi yang mendalam ke dalam ekonomi global, perdagangan luar negeri China semakin melonjak dan mampu mempertahankan tingkat perdagangan luar negeri lebih dari 20\% setiap tahun. 
Ekspor-impor menjadi empat kali lipat, produknya terjual ke seluruh dunia dan secara bertahap negara ini ditetapkan sebagai negara dengan perdagangan besar. Peningkatan ekspor dan impor tidak hanya berkontribusi pada pertumbuhan ekonomi China, tetapi juga mendorong pertumbuhan ekonomi Global. China juga menjadi motor utama yang mendorong bagi pertumbuhan ekonomi di wilayah Asia dan negara tetangganya. Model ekonomi Asia menjadi berpusat di China. Alasan apa yang membuat China begitu kompetitif dalam perekonomian global, disini kita akan menganalisa kekuatan kompetitif China dibandingkan dengan negara lain sehingga dapat mengalami pertumbuhan tanpa krisis.

Pertama, sesuai dengan Konsesus Beijing, China menekankan pada pola pengembangan pembangunan berbasis inovasi, China mengadopsi strategi mengejar ketertinggalan dalam ilmu pengetahuan dan teknologi dan menerapkan ke dalam strategi negara yang berorientasi inovasi. China berhasil mengadopsi perkembangan teknologi negara maju dengan sebuah inovasi atau inovasi ulang, penyerapan sains, dan teknologi eksternal serta memperoleh keunggulan unik dalam beberapa aspek. Keunggulan adopsi inovasi China bisa menghasilkan produk dengan skala menyamai teknologi negara maju namun dengan biaya yang lebih rendah di pasaran, hal tersebut dikarenakan strategi mengejar ketertinggalan China lebih mengedepankan biaya penelitian dan pengembangan yang relative kecil biayanya, serta menggunakan tenaga kerja yang relative murah karena jumlah populasinya yang banyak. Dampak dari penerapan strategi yang berorientasi inovasi ini pertumbuhan ekonomi China berlangsung cepat dengan proporsi sebesar 45,62\% dari sektor kemajuan teknologi dan jumlah Produk Domestik Bruto mencapai $7 \%$.

Kedua, China menolak teori Keynesian tentang paradox of saving, yang mengharuskan masyarakat untuk tetap mempunyai sifat konsumerisme meskipun dalam keadaan inflasi dan berhutang itu adalah suatu hal yang lumrah untuk memperbaiki krisis. Kaum Keynesian memandang menabung akan berbahaya bagi pertumbuhan ekonomi karena menghilangkan uang dari sirkulasi dan menurunkan efisiensi faktor produksi. Namun China tidak berpikir seperti itu, negara ini punya perspektif sendiri, mereka menilai bahwa teori yang dikemukan oleh Keynesian itu salah karena berhutang 
ketika sedang pailit akan menambah ketimpangan ekonomi karena pengeluaran akan jauh lebih besar dari pemasukan. Dan menabung akan menciptakan modal yang memungkinkan ekspansi produksi, simpanan bukan hanya sarana untuk meningkatkan kemampuan belanja seseorang, tetapi juga bumper penting untuk melindungi perekonomian dari hal yang tak terduga. China memiliki likuiditas internasional yang kuat, cadangan devisa yang dimiliki pada tahun 2009 berkisar USD 2.3991 trilliun menempati peringkat nomor satu dunia dari hasil ekspor dan investasi sehingga ketika terjadi krisis perekonomian China masih bisa tetap mempertahankan kestabilan.

Ketiga, impian negara China adalah membangun negara sosialis yang kuat dan makmur, hal tersebut tidak akan terwujud apabila kondisi sumber daya masyarakatnya tidak mendukung maka dari itu agar terjadi pemerataan sosial dan ekonomi serta transfer teknologi dan ilmu pengetahuan yang merata, pemerintah berupaya menekankan pada pengembangan produktivitas dan meningkatkan standar kehidupan dengan pola urbanisasi, meningkatkan nilai tambah jasa, perdagangan, perolehan pekerjaan penuh bagi tenaga kerja dan mewujudkan modernisasi negara dan menuju ke kekuatan dunia. Dan untuk merealisasikan hal tersebut Partai dan pemerintah berupaya mendukung matapencaharian dan kesejahterahteraan masyarakatnya, namun tetap mengantarkan masyarakatnya untuk berupaya mandiri. Maksudnya pemerintah tidak menciptakan kekayaan, tetapi masyarakatnya yang harus menciptakan dan kemudian mendukung pemerintah melalui pajak, karena menurut China pemerintah yang ingin mendukung masyarakatnya dengan menciptakan kekayaan hanya akan menimbulkan kelebihan cetak mata uang, inflasi yang tak terkendali, kebangkrutan negara, badai keuangan, dan risiko ekonomi. Caranya, pemerintah akan mendorong bisnis startup, mengembangkan usaha kecil, memperluas perdagangan jasa, meningkatkan proporsi populasi berpendapatan menengah, dan mempertahankan kenaikan gaji karena semakin meningkatnya permintaan tenaga kerja. Serta pemerintah pusat memberikan subsidi pada investasi rumah murah bagi para urbanisasi dan orang-orang perkotaan yang pendapatannya rendah serta tidak mampu membeli.

Keempat, membangun industri ketiga, sejak reformasi dan keterbukaan jalur urbanisasi tiongkok telah mengakumulasi dan industri perkotaan harus menyerap tenaga 
kerja yang mengalir akibat pola urbanisasi. Perkembangan industri ketiga adalah faktor penting dalam mengatasi hal tersebut, dan juga merupakan hukum objektif dan tren dalam transfer dan alokasi tenaga kerja di antara industri primer, sekunder, dan tersier. Teori yang menyatakan bahwa perdagangan jasa tidak menciptakan nilai, teori ini menentang urbanisasi dan menganjurkan membangun kota-kota produksi, tetapi menentang kota yang menguntungkan untuk hidup dan konsumsi, yang menyebabkan perdagangan jasa sangat lambat, teori tersebut dicoba oleh China secara terbalik. China berupaya mendorong pengembangan di sektor perdagangan jasa atau industri ketiga, meskipun dalam 30 tahun pertama setelah berdirinya hanya berkembang sebesar 2,1\%, China berupaya melihat kondisi nasionalnya kembali dan menganalisa kelemahan strateginya. China mulai menyadari kesalahan bahwa industri ketiga yang dibuat sebelumnya bahwa sektor jasa, termasuk perdagangan, hanya mentransfer dan merealokasi nilai dan telah menyadari bahwa sektor jasa juga dapat menciptakan nilai. Industri ketiga telah dimasukkan ke dalam perhitungan nilai tambah ekonomi nasional. China juga mempromosikan urbanisasi dengan mengubah struktur yang berpusat pada produksi yang mengabaikan tingkat kehidupan dan konsumsi budaya dan secara signifikan meningkatkan proporsi pekerjaan di industri jasa.

\section{d. Ekspansi China}

40 tahun Deng Xiaoping membuka reformasi dari sistem ekonomi terpusat ke sistem ekonomi pasar secara berangsur-angsur, rahasia mendasar dari keberhasilan pembangunan ekonomi tiongkok terletak pada awal masa reformasi dengan dibukanya SEZ (special economic zones) di beberapa provinsi seperti Guandong, Fujian, Hainan, Zhenjiang, lalu dilanjutkan ke 14 kota di pesisir tiongkok. Hal tersebut dilakukan untuk menarik kegiatan investasi khususnya FDI, dan perdagangan ekspor khususnya perdagangan internasional (orientasi ekspor), dari situ ekonomi pasar semakin disebarluaskan secara evolusioner ke bagian china dan reformasi bertahap seperti pembukaan neraca modal, dan finansial ke negara lainnya.

Bergabungnya China dengan berbagai organisasi internasional seperti WTO, semakin memperluas pasar produk China di perdagangan Internasional. China semakin 
merambah ke sektor bisnis global, baik dalam produk barang dan jasa maupun sektor investasi. China juga banyak melakukan hubungan dagang dengan dibukanya kerjasama pasar bebas dengan negara sekitarnya seperti ACFTA (ASEAN-China Freetrade Area) yang ditandatangani di tahun 2002 dan mulai diimplementasikan di tahun 2010 yang merupakan kerjasama perdagangan bebas antara 10 negara anggota ASEAN dengan China. selain perjanjian kerjasama perdagangan bebas, China juga membuat langkah yang lebih maju yang memiliki kedalaman integrase yang lebih maju daipada ACFTA yaitu RCEP (Regional Comprehensive Economic Partnership), bagi negara ASEAN dan non anggota asean seperti Jepang, Korea, Australia, dan New Zealand. Dan merunut perjanjian kerjasama perdagangan bebas China semakin memperluas kerjasama sampai ke wilayah Asia Pasifik lewat FTAAP (Free Trade Area of the Asia Pasific).

Untuk lebih mendominasi dunia, China juga perlu melakukan upaya globalisasi mata uang agar RMB (Renmimbi) dapat beredar luas di pasar global. Globalisasi mata uang adalah representasi dari daya ekonomi dan kekuatan nasional komperehensif dari suatu negara. Hanya setelah negara memperkuat daya ekonominya dan kekuatan nasional yang komperehensif maka negara tersebut dapat memperbanyak perannya dalam hasil dan perdagangan ekonomi dunia. RMB telah beredar melintasi batas nasional dan telah dipergunakan di negara kawasan Asia dan sekitarnya. Seiring dengan tumbuhnya perekonomian China, RMB telah meng-global dan diprediksikan akan menjadi tren jangka panjang. Bila melihat dari proses peredarannya dan sebagaimana fungsi mata uang secara resmi, China telah secara aktif berpartisipasi dalam kerja sama mata uang kawasan Asia Timur dan mendirikan mekanisme bantuan timbal balik yang lentur. China memperluas peredaran dan daerah dagang mata uangnya dan akan memperbesar penawaran akan mata uangnya. Untuk itu China juga semakin luas menjalin kerjasama bilateral swap dengan Thailand, Jepang, Korsel Phillipina dengan inisiasi terkait kesepakatan renmimbi (Chiang May insisatives).

Dari inisiatif Chiang Mai, secara bertahap bergeser dari persetujuan bilateral menjadi multilateral, china secara aktif terlibat dalam penyediaan dana untuk cadangan valuta asing regional demi meningkatkan mekanisme pertolongan finansial timbal balik 
regional yang bersifat multilateral. Selain itu China tetap menjaga kestabilan nilai mata uang renmimbi agar dapat bersaing dan menguasai perdagangan di pasar Internasional. China menjaga nilai tukar renmimbi tidak terlalu kuat dan terlalu lemah, sehingga dapat mengekspor dengan lebih banyak, caranya dengan banyak membeli mata uang dollar. Dollar tersebut diputar kembali untuk membeli surat utang bernama "Treasury Securities" yang dikeluarkan oleh AS, lalu dipinjamkan kembali kepada AS melalui pemberian surat utang. China selalu mendekati posisi paling atas untuk pembelian Tbills dan dari situ China secara konsisten memberi pinjaman lebih dari \$1 trilliun kepada AS melalui pemberian surat utang (Zuhra, 2018).

Sejak tahun 2009, China telah menandatangani persetujuan multilateral untuk menyediakan 32\% dari total pendanaan 120 miliar US\$, sama dengan andil pendanaan Jepang. Di tahun 2008, Bank Rakyat China telah menandatangani 8 persetujuan bilateral pertukaran mata uang dengan Bank sentral atau otoritas moneter dari Korea Selatan, Hongkong, Belarus, Malaysia, Indonesia, Argentina, Islandia, dan Singapura dengan total 803, 5 milyar yuan. Dan pada bulan desember 2006, RMB dipergunakan sebagai mata uang cadangan di Filipina, dan disusul bank sentral di Malaysia, Korea Selatan, dan Kamboja (Yulu, 2019).

Perkembangan terbaru adalah dengan adanya kebijakan China tentang inisiatif perdagangan terkait Belt and Road Initiatives (BRI) sejak tahun 2013 yang berupaya membangun konektivitas antara China dengan berbagai negara Asia, Afrika, dan Eropa lewat pembangunan kerja sama terkait infrastruktur yang sering disebut OBOR (One Belt One Road). Pembangunan konektivitas tersebut sebenarnya merupakan upaya kebangkitan kembali hubungan China dengan wilayah -wilayah tersebut yang sudah terjalin ratusan tahun melalui jalur sutra dan semakin mempererat kerjasama terutama di bidang ekonomi dan politik. China juga membuka sistem pendanaan melalui Bank China yaitu AIIB (Asian Infrastructure Investment Bank) untuk membantu mendanai pembangunan infrastuktur di Asia yang berjalan cukup lambat.

Dapat dilihat pertumbuhan ekonomi China berkembang pesat karena strategi bisnis mereka yang cukup mengglobal, tidak hanya melalui jalur kekuasaan China tetapi 
juga direalisasikan dalam bentuk softdiplomacy melalui proses kerjasama ekonomi dan pembangunan infrastruktur. Tanpa disadari China telah meng-ekspansi semua negara melalui pertumbuhan ekonominya yang cukup pesat, dapat dilihat dari mulai mengglobalisasinya mata uang RMB dan perluasan kerjasama ekonomi ke berbagai sektor membuat pertumbuhan ekonominya menyumbang 7,9\% dari output ekonomi global dan membuat China dapat membantu dunia dalam memulihkan perekonomian dunia menghadapi krisis global.

\section{e. Respon dunia terhadap kebangkitan ekonomi China}

Meluasnya ekspansi China ke seluruh dunia mendorong pertumbuhan ekonomi China semakin cepat, China semakin berintegrasi mendalam ke perekonomian global yang membuat perdagangan luar negeri China melonjak. Impor Ekspor China meningkat 4 kali lipat, China menjadi negara pengekspor terbesar dan negara pengimpor terbesar kedua dan berhasil mempertahankan peningkatan perdagangan sebesar $20 \%$ pertahun. Keberhasilan China di bidang ekonomi ini telah menimbulkan berbagai respon dari seluruh dunia yang bersifat positif dan negative. China mengalami proteksionisme perdagangan oleh Amerika Serikat, yang memicu perang dagang diantara keduanya. Sebagaimana diketahui AS mulai menerapkan tarif Impor produk perdagangan China sebesar 10-25\%, alasannya karena China mengalami surplus perdagangan yang merugikan AS. AS merasa mengalami deficit dalam neraca perdagangan dikarenakan, impor barang dan jasa AS dari China mencapai 522,9\% miliar dollar AS, sementara ekspornya ke China hanya 187,5 miliar dolar AS. Dengan kata lain AS mengalami defisit sebesar 365,4 miliar dolar AS. Persoalan ini kemudian memicu China untuk menerapkan hal yang sama terhadap AS dengan jumlah tarif yang hampir sama sekitar 144 miliar dolar AS. Selain itu ditemukan hasil investigasi oleh USTR (United States Trade Representatives) yang membuktikan bahwa China telah melanggar salah satu aturan Trade Act 1974 section 301 di AS mengenai “Intellectual Property and Technological Transfer Scheme” (Yulu, 2019).

Selain mendapat respon negative dari AS, China juga mendapat kecaman keras dari Kanada atas perintah AS, pemilik perusahaan teknologi raksasa China yaitu 
Huawei "Meng Wanzhou" ditangkap dikarenakan kasus yang sama dengan pola tuduhan Amerika Serikat. Tidak hanya wilayah AS dan sekitarnya saja respon yang diterima China, tetapi beberapa negara tetangga lainnya. Switzerland yang telah ikut bekerjasama dengan China melalui "Trade Agreement between Switzerland and China" di tahun 2013, ikut melayangkan aksi protes terhadap kerjasama bisnis dengan China. Switzerland merasa kurangnya rasa kemanusiaan dari perusahaan China, sebagai contoh masih banyaknya sistem buruh dengan standar upah rendah dan jam waktu yang melebihi batas jam kerja normal atau masih berlaku sistem kerja paksa bagi para pekerja. Banyak masyarakat yang tergabung dalam komunitas "The Society for Threatened People (GfbV)" dan "Tibet organisations" yang mengajukan petisi kepada pemerintah dan parlemen Swiss untuk melindungi para pekerja Tibet di Swiss. Dalam sebuah laporan yang diterbitkan pada musim semi, LSM-LSM ini menganalisis dampak Perjanjian Perdagangan Bebas pada komunitas Tibet. Mereka menemukan bahwa sejak FTA ditandatangani, komunitas Tibet di Swiss semakin dan langsung menjadi sasaran "permainan kekuatan China."

Lebih dari 80 perusahaan Swiss telah diakuisisi oleh China, China berinvestasi sekitar \$46,3 juta di Switzerland. Pertumbuhan ekonomi negara China semakin memberikan pengaruh bagi kehidupan para pebisnis di Swiss dan menimbulkan kritikan politik. Sejalan dengan perjanjian dagang antara China dengan AS dan Jerman, Switzerland juga tidak memiliki hak veto untuk mencegah pengambilalihan infrastruktur yang dinilai penting secara strategis, misalnya produk listrik. Politisi juga marah karena perusahaan Swiss masih menghadapi rintangan birokrasi untuk berinvestasi di China. Mereka mengatakan China melindungi pasar domestiknya dari pembeli asing, sementara gerbang ke Swiss terbuka lebar bagi investor Cina. Badan intelijen Swiss mencatat dalam laporan statusnya tahun 2016: terjadi pengambilan alih saham perusahaan-perusahaan Swiss dan juga hotel-hotel di Swiss oleh China, China berusaha untuk memerah pengetahuan Swiss dan mendapatkan merek-merek Swiss, bersama dengan reputasi baik mereka (swissinfo, 2018). Maka dari itu pemerintah Switzerland untuk menanggapi isu-isu perdagangan yang muncul di negaranya melayangkan tuntutan dan respon negative kepada pemerintah China. 
Inisiatif perdagangan One Belt One Road (OBOR) juga menimbulkan banyak respon negative, selain diterima secara positif oleh mitra kerjasama China. penandatanganan MOU proyek-proyek BRI masih menimbulkan kecurigaan akan banyaknya jebakan hutang. Pemerintah China berusaha meyakinkan setiap mitranya bahwa akan melaksanakan sesuai komitmen tanpa menyebabkan mitranya terkait pada jebakan hutang. Namun banyak fakta yang membuat perkiraan negara mitra China bukan hanya sekedar kecurigaan, contohnya kasus gagal bayar proyek Srilanka dalam kerjasama BRI. Srilanka gagal membayar pinjaman modal infrastruktur sehingga negara tersebut harus melepas $70 \%$ saham pelabuhan Hambatota kepada sebuah BUMN China. Hal tersebut juga terjadi pada Malaysia dan Pakistan yang sempat merasa perjanjian kerjasama dengan China tidak berjalan seimbang. Lebih lanjut sebanyak 50 \% merasa bahwa proyek BRI dapat membawa negara ASEAN berada di bawah ekspansi China. Menanggapi respon tersebut, pemerintah China berupaya membuat perjanjian ini lebih transparansi dan nol toleransi terhadap praktik korupsi dalam setiap proyek kerjasama (Bhaskara, 2018).

Dominasi China yang menimbulkan protes keras dari beberapa negara, juga mulai mengkhawatirkan beberapa negara tetangganya seperti Japan dan Vietnam, kedua negara tersebut membentuk sebuah aliansi di bidang militer meskipun selanjutnya lebih kepada kerjasama ekonomi. Aliansi ini lebih kepada strategi kerjasama global, karena munculnya kasus konflik Laut China Selatan, Japan ingin membantu Vietnam membuat strategi pertahanan militer apabila nantinya akan terjadi penyerangan langsung dari kekaisaran China. Maka dibuatlah “Advance Cooperation” pada tanggal 3 mei 2019. Kerjasama ini terjadi karena Japan merasa kepentingan yang dimilikinya sedikit bersinggungan dengan kedaulatan China di bagian laut China Timur yang mulai mengganggu keamanan maritim wilayah Japan akibat armada penangkapan ikan. Pada dasarnya ada lingkaran kecemasan yang membentang dari New Delhi ke Canberra dan Jakarta dan Hanoi dan Tokyo. Jadi ini mungkin retorika yang bertujuan memberi sinyal bahwa ada kekhawatiran bersama antara Japan dan Vietnam, yang mengarah pada respons kolektif akan dominasi China (Jennings, 2019). 
Namun selain mendapat respon negatif dari berbagai negara mitranya, kebangkitan ekonomi juga dinilai positif oleh beberapa negara tetangga China sebagai poros ekonomi di wilayah Asia. Banyak juga yang telah memberikan respon positif terhadap China, beberapa negara kecil di wilayah Asia dan Afrika, Eropa. Melihat diplomasi hutang yang dijalankan China melalui inisiatif OBOR dan peminjaman dari AIIB ini sebagai penggerak perekonomian mereka. Pinjaman murah dalam bentuk investasi dengan pembangunan infrastruktur, melalui inisiatif OBOR atau BRI dianggap menguntungkan bagi negara-negara kecil seperti Brazil, Kazhakastan, Malaysia, Indonesia, Filipina, Thailand mencari cara untuk menyeimbangkan terhadap kebangkitan ekonomi China. Penyeimbangan yang dimaksud tersebut yaitu dengan penerimaan bantuan dana tersebut meskipun terhitung utang dapat membantu peningkatan jumlah perkapita pendapatan masyarakat di masing-masing negaranya karena akan mendorong faktor produksi ekonomi yang dianggap mati dapat terbantukan kembali dengan adanya investasi dari China, meskipun negara-negara tersebut akan sedikit bertaruh dan memainkan permainan Zero Sum Game ketika berbisnis atau melakukan perdagangan dengan China, tetapi memungkinkan mereka untuk melakukan perlindungan terhadap bisnis yang dijalankan melalui jalur negosiasi.

\section{f. Strategi Respon untuk menyikapi Kebangkitan Ekonomi China}

Banyak orang yang baru menyadari kebangkitan China ketika mata uang China telah dipergunakan secara luas dan telah memasuki saham para pebisnis secara global, padahal China telah berupaya untuk memasuki perdagangan global sejak Deng Xiaoping mulai membuka reformasi dan keterbukaan. Negara-negara lain yang menyadari akan kebangkitan ekonomi China mulai terkena dampak dari peristiwa tersebut dan akhirnya menjadi lebih menaruh perhatian terhadap China dan respon yang di timbulkan berbagai macam meskipun akhirnya semua respon tersebut dapat diinterpestasikan sebagai bentuk antisipasi terhadap dominasi ekonomi China.

Tidak bisa dipungkiri China bergerak dengan cukup cepat, hanya memerlukan waktu 8,9 tahun untuk dapat menambah pendapatan perkapita masyarakatnya menjadi dua kali lipat. Tidak banyak negara yang memahami kenapa China bisa bangkit secepat 
itu, dan diramalkan akan menyamai kebesaran AS. Tetapi bila disadari, pertumbuhan ekonomi China juga bukan sesuatu yang sulit untuk dipahami, bergerak dari "China Dream" untuk menjadi negara yang kuat dan memakmurkan rakyatnya sendiri dengan melihat kondisi nasional masyarakatnya, China selalu berupaya mentransformasi model pembangunan nya untuk dapat terus tumbuh berkembang dan masuk ke jajaran negara ekonomi maju hanya saja tidak banyak negara yang memperhitungkan China, dan mengenal strategi China, sehingga menyangkal terhadap perkembangan dominasi ekonominya sebagai sebuah bentuk ekspansi ekonomi dan mulai merasa menjadi sebuah gangguan bagi sistem perekonomian negara lainnya. Penyangkalan tersebut adalah sebuah bentuk dari ketidaktahuan atau ketidaksadaran akan sesuatu yang akan terjadi di luar perkiraan mereka, kita hanya cenderung melihat dunia baru dengan memakai kacamata sendiri dan cenderung melihat masa lalu dan berpikir itulah segalagalanya sama seperti kita selalu berpikiran bahwa tidak akan ada negara lain yang dapat menyaingi imperialism dari AS. Padahal ada hal lain yang akan terjadi dan tidak kita prediksikan di luar sana. Maka dari itu kita perlu mengubah pola pikir kita untuk menyiasati akan hal yang tidak terprediksikan sebelumnya sehingga apabila terbukti kebenarannya akan memudahkan kita dalam meresponnya karena telah memiliki strategi khusus atau telah siap mengantisipasi. Perkembangan ekonomi China akan menimbulkan respon positif, apabila negara-negara sekitarnya telah menyadari dari awal akan terjadinya siklus perputaran ekonomi global, dan akan ada sebuah negara yang akan mengalami transformasi identitas terhadap struktur ekonomi global. China sebelumnya hanya disadari sebagai negara di wilayah Asia yang kultur identitas budayanya sangat khas dan memiliki tingkat kepadatan penduduk yang cukup tinggi, namun tidak banyak yang menyadari bahwa identitas tersebut akan memiliki banyak spectrum yang dapat membantu meningkatkan pertumbuhan ekonominya. Bila setiap negara menyadari disruption yang akan dilakukan oleh China dari awal, tentu tidak akan menjadi suatu masalah. Maka dari itu sangat diperlukan Mindset Disruption sejak awal, yang disesuaikan dengan tuntutan perubahan zaman, zaman digital yang serba cepat, mobilitas tinggi, informasi yang melekat pada setiap pemimpin, pelayanan, atau calon pemimpin sehingga apabila disruptor atau pesaing telang menunjukkan kemampuannya 
kita telah siap menghadapinya dengan strategi yang lebih matang sehingga tidak mudah terdisrupsi. Krisis finansial beberapa kali dialami secara global, namun krisis tersebut tidak dialami oleh China atau terkena imbasnya karena China telah siap mengantisipasi dengan model pembangunan pertumbuhan anti krisis dengan metode yang telah disiapkan berkaca dari masa lalu dan kondisi nasional masyarakatnya. Mereka lebih kreatif dan inovatif, dengan strategi mengejar ketertinggalan dari negara maju, karena di pola pikir mereka telah tertanam "China Dream" sehingga mindset disruption telah dijalankan dari awal. Lebih baik menyerang daripada diserang terlebih dahulu, dan sebaliknya kita juga perlu merespon kebangkitan China dengan menyiapkan Mindset Disruption yang telah siap beradaptasi sesuai segala situasi dalam sistem ekonomi politik internasional. Mindset disruption akan membentuk Self disruption yang artinya akan meremajakan cara berpikir agar lebih realistis, mencoba berdamai dengan transformasi dunia dan mengubah ancaman menjadi peluang membuatnya lebih sederhana dengan tentunya menciptakan strategi dan teknologi baru yang berorientasi ke masa depan.

China banyak melakukan pola kerjasama dalam mendorong pertumbuhan ekonomi negaranya, salah satunya dengan inisiatif OBOR (One Belt One Road), dan membuka investasi asing di beberapa negara, sehingga menimbulkan kewaspadaan negara yang bekerjasama karena China dianggap menjalankan politik diplomasi Hutang ke negara mitranya. Dalam merespon hal tersebut tidak perlu terlalu frontal apabila kita telah memiliki mindset disruption, kita hanya perlu mengikuti arus kerjasama tersebut dan menciptakan peluang bukan menjadikannya ancaman. Setiap negara pasti punya Complementary Interest atau kepentingan yang saling melengkapi, mengapa tidak memanfaatkan hal tersebut dengan tetap menjadikan pertumbuhan ekonomi China sebagai pendorong pertumbuhan ekonomi setiap negara mitra. Ada 3 faktor yang perlu diketahui ketika menjalankan politik kerjasama, yaitu kepentingan yang saling menguntungkan, bayangan tentang masa depan, dan jumlah pemain.

Ketiga faktor tersebut sangat diperlukan untuk menjalankan politik kerjasama. Ketika China menawarkan bantuan kerjasama yang lebih dikhususkan ke bidang investasi, negara mitra perlu menganalisa terlebih dahulu keuntungan apa saja yang 
akan didapatkan dari kerjasama tersebut. Dan diperlukan hukum yang mengikat sehingga tidak hanya menguntungkan satu pihak sehingga akan ada jaminan kerjasama tersebut akan berupaya membangun kemakmuran bersama. Misalkan kerjasama Indonesia-China dalam inisiatif OBOR, China menawarkan bantuan investasi untuk membantu pembangunan infrastruktur di Indonesia, dengan syarat proyek Turnkey atau semua pekerja, alat, dan modal semua disiapkan oleh China. Indonesia punya kebutuhan modal untuk pembangunan tersebut, namun menilai bahwa kerjasama yang ditawarkan oleh China tidak menguntungkan bagi Indonesia karena tidak akan ada peluang penciptaan lapangan pekerjaan bagi masyarakat Indonesia, dan transfer teknologi disini bahkan ongkos produksi akan jauh lebih mahal karena penyediaan bahan baku dari China, hal ini akan lebih banyak pasokan impor daripada ekspor ke China. Namun apabila pemerintah Indonesia dapat memainkan peran nya dengan baik dalam melakukan negosiasi, kerjasama ini akan menjadi peluang bagi Indonesia yang memposisikan sebagai negara net-oil importer.

Salah satu keinginan China bekerjasama dengan Indonesia, karena Indonesia merupakan ladang pemasok energy bagi pemenuhan kebutuhan energy China, Indonesia bisa menawarkan kerjasama lebih ke bidang industry ekstraktif, yaitu china harus mau menerima ekspor dari Indonesia dalam bentuk bahan setengah jadi atau barang siap pakai sehingga Indonesia dapat memaksimalkan marginal produksinya. Dan Indonesia perlu memperbaiki sistem hukumnya sehingga tidak mudah terkecoh dengan aturan yang dibuat oleh China, seperti diperbolehkan banyak tenaga kerja asing dari China bekerja di Indonesia, namun dengan persyaratan upah tenaga kerja nya harus disesuaikan dengan standar pekerja Indonesia bahkan jauh lebih murah, dan hanya pekerja yang bisa berbahasa Indonesia yang dapat diterima, serta peningkatan system pajak bagi para pekerja asing yang bekerja di Indonesia. Hal tersebut akan menekan kerugian kerjasama yang dilakukan oleh China dalam menjalankan diplomasi hutang melalui inisiatif OBOR. Jumlah pemain juga sangat penting, Indonesia harus memanfaatkan posisi tawarnya di system perpolitikkan internasional, jadi apabila terjadi pengingkaran, kelemahan Indonesia dapat teratasi dengan bantuan rezim internasional. Misalkan hokum Indonesia yang tidak terlalu kuat menyebabkan China dapat mengatur 
dengan mudah perjanjian kerjasama dengan Indonesia, namun apabila China melakukan kecurangan, Indonesia dapat meminta bantuan WTO sebagai alternative dispute Settlement dalam penyelesaian konflik kerjasama kedua negarany. Cara tersebut sesuai dengan konsep Constructive engagement and Hedging dimana lebih kepada memilih middle position.

Indonesia harus punya posisi netral dalam perpolitikkan dunia, namun juga harus mengantisispasi dalam setiap proses kerjasama yang dilakukan dengan negara lainnya. Kerjasama dengan China bukan berarti hanya merugikan sebelah pihak, tetapi juga akan memberikan keuntungan bagi Indonesia untuk mendistribusikan kemakmuran ke seluruh masyarakat Indonesianya dengan proses pembangunan infrastruktur. Dikarenakan ancaman kerjasama oleh China belum pasti, mengapa tidak mencoba ikut berpartisipasi terlebih dahulu dengan berbagai mitra strategis sehingga dapat membangun koalisi, constructive engangement juga akan mendorong transisi sistem politik dalam negeri lebih ke ranah kerjasama ekonomi yang akan mendorong pertumbuhan ekonomi dan pembangunan nasional yang pada gilirannya akan mendukung keberlangsungan demokratisasi suatu negara. Apabila pola kerjasama tersebut dinilai memiliki ancaman, kenapa tidak menerapkan strategi Hedging bagi dominasi China yang dirasa merugikan, yaitu menggunakan bantuan dari sebuah atau beberapa rezim internasional untuk menggunakan sanksi langsung kepada China agar negara lainnya tetap berempati kepada negara yang merasa dirugikan dan berinisiatif membantu.

Respon ini yang menurut penulis sangat diperlukan dalam menghadapi dominasi ekonomi China, setiap negara harus berpikir disruptive dalam menghadapi era globalisasi, karena tuntutan zaman telah berubah bukan menyelesaikannya dengan tindakan keras atau sikap antisipasi terhadap pertumbuhan ekonomi global tetapi harus mengikuti dari belakang dan terus bergerak setingkat lebih maju untuk menyusul ketertinggalan agar bisa bermain dalam ekonomi politik internasional. 


\section{E. Simpulan}

Kinerja ekonomi China dalam empat dekade terakhir sangat mengesankan, dan china menjadi mitra dagang hampir seluruh dunia, dan memainkan peran yang sangat penting terhadap sistem perekonomian global karena dianggap turut berkontribusi dalam pemulihan krisis global yang terjadi. Namun kinerja tersebut menjadi dua mata pisau yang membuat, keuntungan positif dan negative bagi China dalam menjalankannya. Karena tidak semua negara memiliki respon positif terhadap kebangkitan ekonomi China. respon negative yang banyak diterima China seperti perang dagang, sanksi WTO semakin membuat China disadari keberadaanya oleh masyarakat internasional sehingga menjadi ancaman tersendiri bagi negara sekitarnya. Namun apabila kita bisa menyikapi secara konstruktif, kebangkitan China bukanlah menjadi suatu ancaman tetapi peluang yang bisa dimanfaatkan oleh negara-negara mitranya untuk dapat Catch-Up strategy dalam menangani keterpurukan ekonomi dalam arena perpolitikkan ekonomi global.

\section{Daftar Pustaka}

\section{Buku:}

Chen, Yulu. Reformasi Ekonomi Tiongkok dan Kebangkitan Renmimbi. Jakarta: Yayasan Pustaka Obor. 2019.

Peter D. Schiff \& Andrew J. Schiff. Bagaimana Perekonomian Tumbuh dan Mengapa Runtuh. Jakarta: PT. Gramedia Pustaka Utama. 2016

Nanang Pramuji Mugasejati \& Ahmad Hanafi Rais. Politik Kerjasama Internasional. Yogyakarta: Institute of International Studies Universitas Gadjah Mada. 2011.

Nur Rachmat Yuliantoro \& Hikmatul Akbar. Menghadapi Kebangkitan China. Yogyakarta: Graha Ilmu. 2019

Rhenald Kasali. Disruption. Jakarta: PT. Gramedia Pustaka Umum. 2017

Rhenald Kasali. Self Disruption. Jakarta: PT. Gramedia Pustaka Umum. 2018

Zhou Tianyong. Mimpi dan Jalan Tiongkok menuju Kejayaan. Jakarta: Yayasan Pustaka Obor. 2019 


\section{Jurnal dan Artikel Online:}

Yudi. Kebijakan Fiskal Cina dalam merespon krisis ekonomi Amerika Serikat. Skripsi online. 2014

https://www.weforum.org/agenda/2016/11/china-lead-globalization-after-united-states/, diakses pada tanggal 5 september 2019

https://tirto.id/strategi-cina-agar-bisa-menjadi-penguasa-perdagangan-dunia-calX, diakses pad tanggal 13 September 2019

https://www.swissinfo.ch/eng/emerging-world-power_switzerland-seeks-response-tochina-s-expansion/44451844, diakses pada tanggal 28 Juli 2019

https://tirto.id/ekspansi-proyek-obor-cina-indonesia-diminta-waspadai-jebakan-utangdnpo, diakses pada tanggal 28 Juli 2019

https:/www.economist.com/briefing/2019/07/13/for-how-long-can-todays-globaleconomic-expansion-last, diakses 28 Juli 2019

https://www.globalresearch.ca/china-rise-fall-and-re-emergence-as-a-global-power2/29644, diakses pada 28 Juli 2019 
